\title{
Studi Eksperimen Pengaruh Sudut Penempatan Plat Datar Pengganggu di Depan Returning Blade Terhadap Performa Turbin Angin Tipe
} Savonius

\section{Studi Kasus untuk Rasio Panjang Plat Pengganggu Relatif Terhadap Diameter Sudu Turbin (L/d) $=1,3054$}

\author{
Ainun Nadhifah, dan Triyogi Yuwono \\ Jurusan Teknik Mesin, Fakultas Teknologi Industri, Institut Teknologi Sepuluh Nopember (ITS) \\ Jl. Arief Rahman Hakim, Surabaya 60111 Indonesia \\ e-mail: triyogi@me.its.ac.id
}

\begin{abstract}
Abstrak-Penelitian ini dilakukan pada sebuah wind tunnel subsonic open circuit dengan ditambahkan suatu plat datar pengganggu dengan panjang $(L)=78,324 \mathrm{~mm}$ dan tinggi $(T)=150 \mathrm{~mm}$ yang diletakkan di depan returning blade dari sudu turbin angin yang memiliki diameter $(\mathrm{d})=$ $60 \mathrm{~mm}$, overlap $(\mathrm{a})=14 \mathrm{~mm}$, dan tinggi $(\mathrm{H})=80 \mathrm{~mm}$. Sudut penempatan plat datar dengan sumbu sudu divariasikan pada rentang $0^{\circ}$ hingga $90^{\circ}$ dengan kenaikan $5^{\circ}$. Selain itu bilangan Reynolds dari aliran juga divariasikan pada $6,0 \mathrm{x}$ $10^{4} ; 7,5 \times 10^{4} ; 9,0 \times 10^{4}$. Daya yang dihasilkan turbin dapat diuku dari pengukuran arus dan tegangan listrik yang dihasilkan motor listrik dengan menggunakan multimeter.

Hasil dari penelitian ini adalah dengan adanya penambahan plat datar pengganggu di depan returning blade akan dapat meningkatkan performa dari turbin angin tipe Savonius. Penambahan plat datar pengganggu dengan $L / d=1,3054$ dengan sudut bukaan plat sebesar $40^{\circ}$ pada bilangan Reynolds 60.000 merupakan konfigurasi paling optimum yang diketahui dengan timbulnya peningkatan pada nilai putaran sebesar $263 \%$ dan peningkatan coefficient of power sebesar $460 \%$ yang dihasilkan oleh turbin angin Savonius.
\end{abstract}

Kata Kunci- Performa Turbin Savonius, Plat Penghalang, Variasi Sudut Plat Penghalang.

\section{PENDAhUluan}

$W$ ind turbine dapat berputar akibat adanya perbedaan gaya drag dari kedua sudu dimana selisih gaya tersebut akan menghasilkan torsi yang jika dikalikan dengan kecepatan angular dari turbin akan menghasilkan daya turbin. Untuk mendapatkan daya turbin angin yang lebih besar, dibutuhkan selisih gaya drag yang besar pula. Oleh sebab itu untuk mendapatkan nilai gaya drag yang kecil di daerah returning blade, diletakkan pengganggu berupa plat datar yang dipasang tepat di depan returning blade. Plat tersebut akan digerakkan ke arah advancing blade dengan besar sudut kemiringan yang dapat divariasikan.

Penelitian yang pernah dilakukan oleh Altan et al [1] mengenai peningkatan performa rotor Savonius dengan pengganggu berupa dua buah plat dengan sudut kemiringan paling optimum sebesar $\alpha=45^{\circ}$ dan $\beta=15^{\circ}$.
Dengan pengaturan tersebut performa rotor mengalamipeningkatan yang signifikan yaitu sebesar $38 \%$ pada nilai daya yang dihasilkan.

Penelitian serupa dilakukan oleh Mohamed et al [2] yaitu dengan mensimulasikan turbin angin tipe Savonius ini melalui software metode komputasi fluida yaitu

Fluent dengan analisa turbulensi. Hasil yang didapat oleh penelitian ini adalah performa turbin paling optimum didapatkan pada $\lambda$ (speed ratio) sebesar 1,4 yaitu meningkat sebesar $75,4 \%$. Sedangkan pada rentang $\lambda$ diantara 0,3 hingga 1,4 didapat peningkatan performa paling sedikit sebesar $30 \%$.

Penelitian yang telah dilakukan ini masih dalam upaya untuk meningkatkan performa turbin Savonius dengan menggunakan pengganggu berupa plat datar yang diletakkan di depan returning blade, dengan sudut kemiringan $0^{\circ}$ sampai dengan $90^{\circ}$ dengan kenaikan sebesar $5^{\circ}$ pada bilangan Reynolds $6,0 \times 10^{4} ; 7,5 \times 10^{4}$; $9,0 \times 10^{4}$.

\section{METODE PENELITIAN}

Pengujian dilakukan pada wind tunnel dengan jenis subsonic, open circuit berpenampang segi-delapan dengan panjang $457 \mathrm{~mm}$, tinggi $304 \mathrm{~mm}$ dan lebar 304 $\mathrm{mm}$. Benda yang diujikan adalah turbin angin tipe Savonius dengan diameter sudu $60 \mathrm{~mm}$, tinggi $80 \mathrm{~mm}$ dan terdapat overlap diantara kedua sudunya sebesar 14 $\mathrm{mm}$ sehingga diameter keseluruhan turbin sebesar 106 $\mathrm{mm}$, serta plat datar pengganggu selebar $78,324 \mathrm{~mm}$ dengan panjang $150 \mathrm{~mm}$ yang terbuat dari acrylic. Skema peralatan dapat dilihat pada Gambar 1 . 


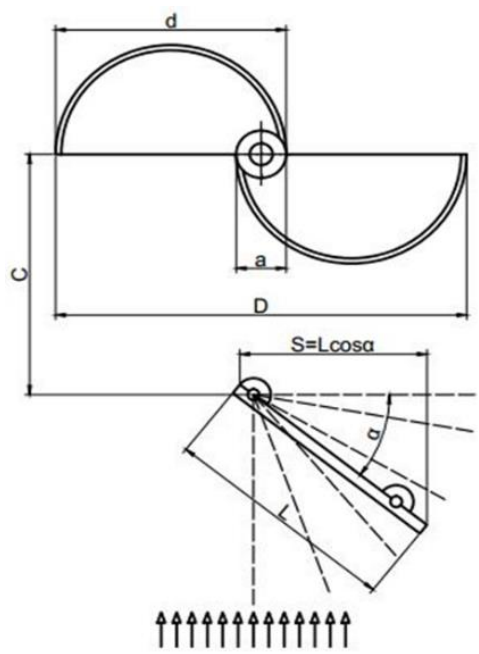

Gambar 1. Skema Peralatan (Tampak Atas)

Pada eksperimen ini, data yang diperoleh adalah nilai putaran dan torsi statis yang dihasilkan turbin, serta tegangan dan arus yang dihasilkan oleh generator listrik yang terhubung dengan poros turbin dengan menggunakan flexible coupling sehingga daya output dari turbin akan dapat dihitung. Untuk mendapatkan kecepatan angin pada bilangan Reynolds yang telah ditentukan, maka digunakan pitot static tube dan manometer. Pengukuran putaran yang dihasilkan turbin digunakan tachometer digital OMEGA seri HHT12 dengan akurasi $\pm 0,01 \%$. Sedangkan pengukuran torsi statis menggunakan torquemeter digital LUTRON seri TQ-8800 dengan akurasi $\pm 0,1$ N.cm dan perhitungan daya dilakukan dengan mengukur tegangan dan arus yang dihasilkan generator listrik dan tersambung dengan rangkaian listrik melalui flexible coupling menggunakan multimeter digital SANWA tipe CD-771 dengan akurasi $\pm 0,1 \%$.

\section{HASIL DAN DISKUSI}

Hipotesa awal dari pengujian ini adalah untuk membuktikan bahwa dengan adanya penambahan penghalang yang diletakkan di depan returning blade turbin angin Savonius akan dapat meningkatkan performa dari turbin. Pengukuran performa ini dapat dilihat dari beberapa parameter yakni: putaran, torsi statis serta daya yang dihasilkan turbin. Berikut adalah hasil dan diskusi dari pengujian yang telah dilakukan.

A. Analisa Putaran Turbin Angin Savonius dengan Penambahan Plat Pengganggu

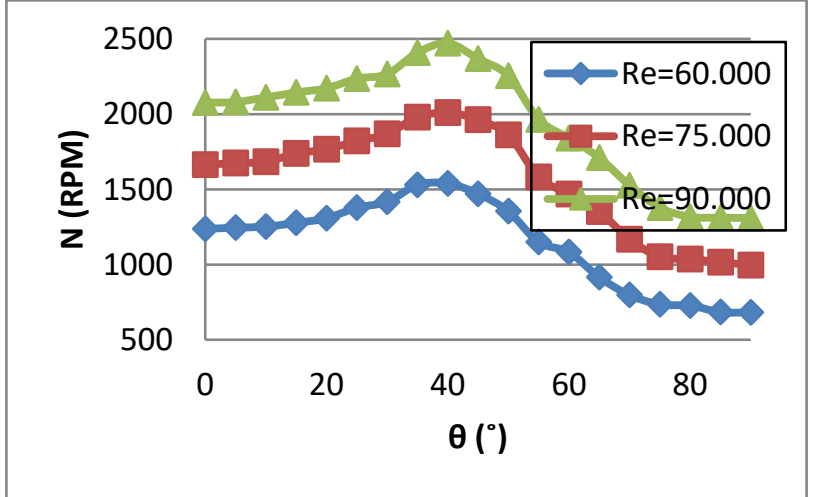

Gambar 2. Grafik putaran turbin berpenghalang dengan fungsi sudut bukaan plat pengganggu
Gambar 2 diatas merupakan grafik dari pengujian yang telah dilakukan dengan cara mengukur putaran yang dihasilkan turbin dengan menggunakan tachometer dengan fungsi sudut bukaan pada berbagai bilangan Reynolds.

Grafik nilai putaran tersebut memiliki trendline yang sama pada berbagai bilangan Reynolds yaitu meningkat hingga mencapai sudut $40^{\circ}$ dan selanjutnya menurun hingga mencapai sudut $90^{\circ}$. Hal ini dapat terjadi karena perbandingan panjang penghalang dengan diameter sudu (L/d) adalah sebesar 1,3054 sehingga pada bukaan sudut sebesar $40^{\circ}$ plat datar pengganggu akan dapat menutup sudu returning secara penuh dan mengarahkan aliran menuju sudu advancing. Tambahan airan udara yang diarahkan oleh plat penghalang inilah yang menyebabkan peningkatan nilai putaran yang paling maksimal. Namun, setelah sudut bukaan menjadi lebih dari $40^{\circ}$ terjadi penurunan nilai putaran, hal ini dikarenakan pada sisi returning akan terbuka kembali sedikit demi sedikit yang awalnya tertutup sepenuhnya oleh plat datar pengganggu. Maka aliran fluida dapat kembali menghantam sudu returning dimana seiring dnegan kenaikan sudut bukaan akan semakin banyak aliran fluida yang dapat menghantam sudu returning.

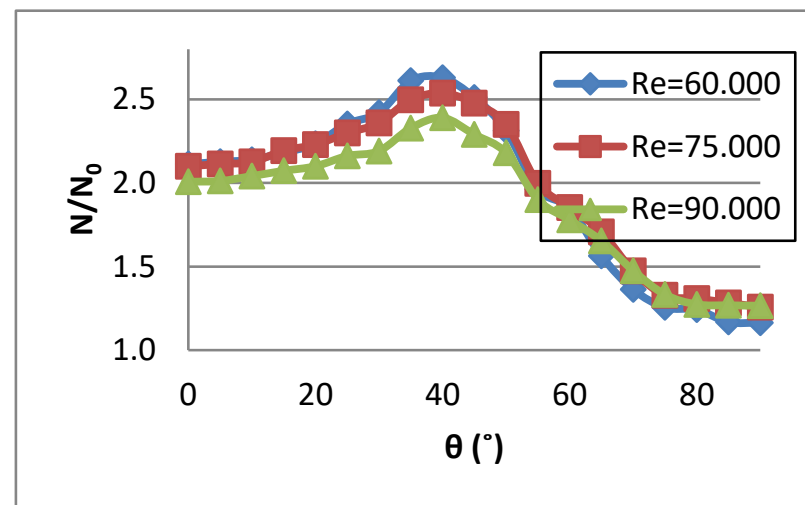

Gambar 3. Grafik perbandingan putaran pada turbin berpenghalang dengan turbin tanpa penghalang dengan fungsi sudut bukaan plat pengganggu

Terlihat pada gambar 3, putaran yang dihasilkan oleh turbin berpenghalang masih lebih tinggi jika dibandingkan dnegan putaran pada turbin tanpa penghalang. Hal ini ditunjukkan dengan nilai $\frac{N}{N_{0}}>1$ untuk semua $\theta$ serta seluruh bilangan Reynolds yang diuji.

B. Analisa Torsi Statis Turbin Angin Savonius dengan Penambahan Plat Pengganggu

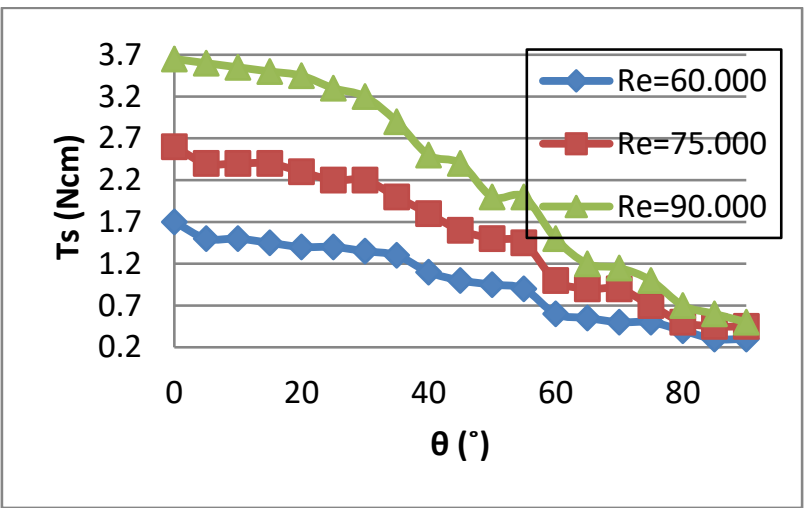

Gambar 4. Grafik torsi statis turbin berpenghalang dengan fungsi sudut bukaan plat pengganggu 
Gambar 4 diatas merupakan grafik dari pengujiang yang telah dilakukan dengan cara mengukur torsi statis dengan menggunakan torquemeter dengan cara menahan turbin pada sudut $0^{\circ}$ tegak lurus dari arah aliran pada berbagai bilangan Reynolds.

Grafik torsi statis tersebut memiliki trendline yang sama pada berbagai bilangan Reynolds yang diuji, yaitu nilai torsi statis tertinggi adalah pada sudut bukaan $0^{\circ}$ dan akan terus menurun seiring dengan pembukaan sudut plat pengganggu. Secara umum nilai torsi statis tertinggi adalah pada bilangan Reynolds 90.000, disusul oleh 75.000 dan grafik terendah pada bilangan Reynolds 60.000. Hal ini dapat terjadi karena seiring dengan peningkatan bilangan Reynolds, maka semakin besar aliran udara yang mengalir sehingga gaya yang menghantam sudu turbin pun semakin besar. Sedangkan perumusan torsi statis sendiri merupakan perkalian dari gaya dan jari-jari dari sudu turbin.

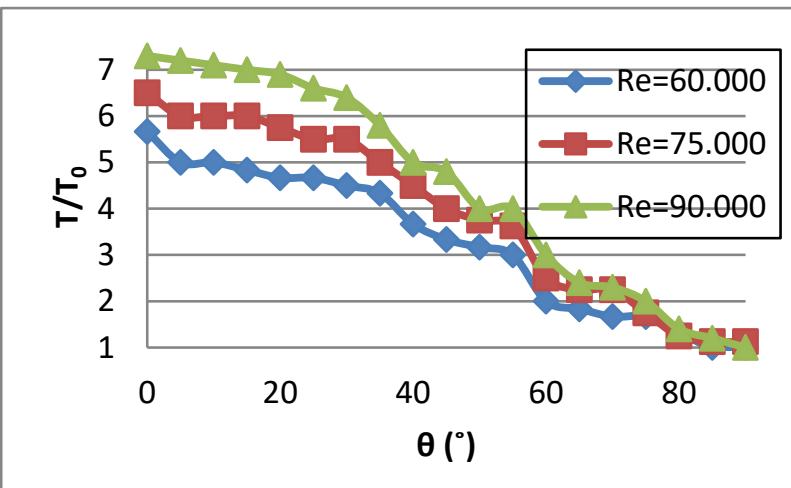

Gambar 5. Grafik perbandingan torsi statis pada turbin berpenghalang dengan turbin tanpa penghalang dengan fungsi sudut bukaan

Gambar 5 menunjukkan perbandingan nilai torsi statis pada turbin berpenghalang dengan turbin tanpa penghalang. Terlihat bahwa nilai yang ditunjukkan adalah $\frac{T}{T_{0}} \geq 1$, hal ini menunjukkan bahwa pada seluruh bilangan Reynolds yang diuji memiliki nilai torsi statis yang lebih baik atau sama dengan pada turbin tanpa penghalang. Namun hal ini terjadi hanya pada beberapa sudut bukaan saja yaitu pada sudut $85^{\circ}$ dan $90^{\circ}$. Hal ini dikarenakan konfigurasi sudut bukaan turbin berpenghalang pada kedua sudut tersebut hampir sama dengan pada turbin tanpa penghalang.

C. Analisa Coefficient of Power Turbin Angin Savonius dengan Penambahan Plat Pengganggu

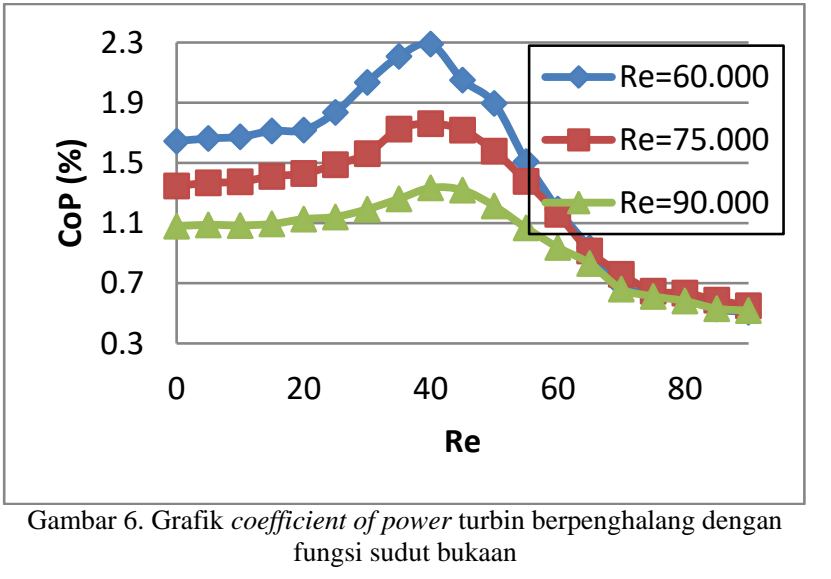

Gambar 6 diatas merupakan grafik nilai coefficient of power fungsi sudut bukaan pada berbagai bilangan Reynolds. Terlihat pada grafik tersebut bahwa peningkatan bilangan Reynolds yang berarti peningkatan kualitas aliran fluida tidak selalu berbanding lurus dengan peningkatan efisiensi daya output berbanding dengan daya input-nya. Karena meski memiliki kecepatan aliran fluida yang terbesar pada bilangan Reynolds 90.000, nilai CoP-nya justru lebih kecil bila dibandingkan dengan bilangan Reynolds yang lebih kecil. Selain itu pada sudut bukaan $40^{\circ}$ juga terlihat memiliki nilai CoP tertinggi, hal ini menunjukkan bahwa pada sudut $40^{\circ}$ merupakan titik paling optimum dalam menghasilkan daya pada turbin angin Savonius pada seluruh variasi bilangan Reynolds yang diujikan.

Selain itu terlihat pula pada gambar 6 bahwa setelah sudut bukaan mencapai $70^{\circ}$ nilai coefficient of power cenderung konstan. Sehingga dapat disimpulkan bahwa saat sudut bukaan mencapai $70^{\circ}$ nilai coefficient of power yang dihasilkan oleh turbin menjadi tidak optimum.

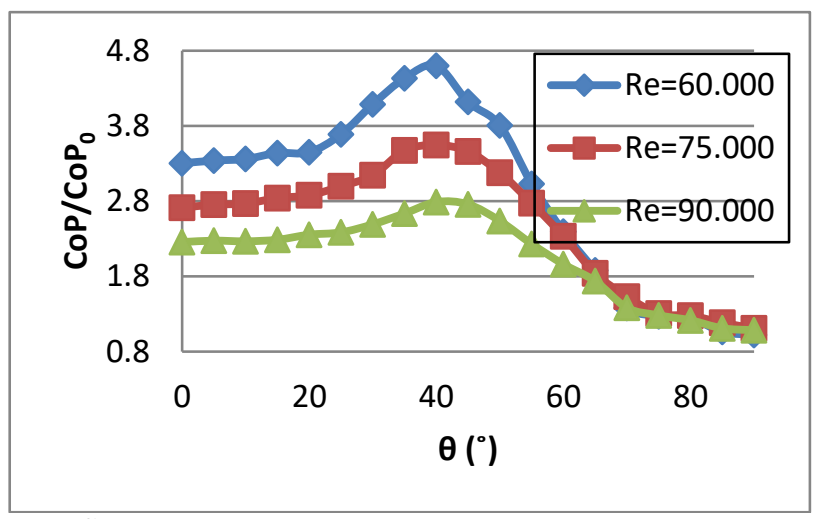

Gambar 7. Grafik perbandingan coefficient of power turbin berpenghalang dengan turbin tanpa penghalang dengan fungsi sudut bukaan

Gambar 7 diatas menunjukkan grafik perbandingan koefisien daya turbin berpenghalang dengan turbin tanpa penghalang dengan fungsi sudut bukaan pada berbagai variasi bilangan Reynolds. Terlihat pada grafik diatas bahwa pada sudut bukaan $40^{\circ}$ merupakan titik paling optimum pada seluruh bilangan Reynolds yang diuji dalam menghasilkan daya output terbesar jika dibandingkan dengan koefisien daya turbin tanpa penghalang. Selain itu terlihat pula bahwa pada seluruh bilangan Reynolds yang diuji serta pada berbagai sudut bukaan memiliki nilai $\frac{C o P}{C o P_{0}}>1$, sehingga dapat disimpulkan bahwa daya yang dihasilkan oleh turbin berpenghalang lebih optimum dibandingkan dengan turbin tak berpenghalang.

D. Analisa Coefficient of Power Turbin Angin Savonius Pada Berbagai Bilangan Reynolds

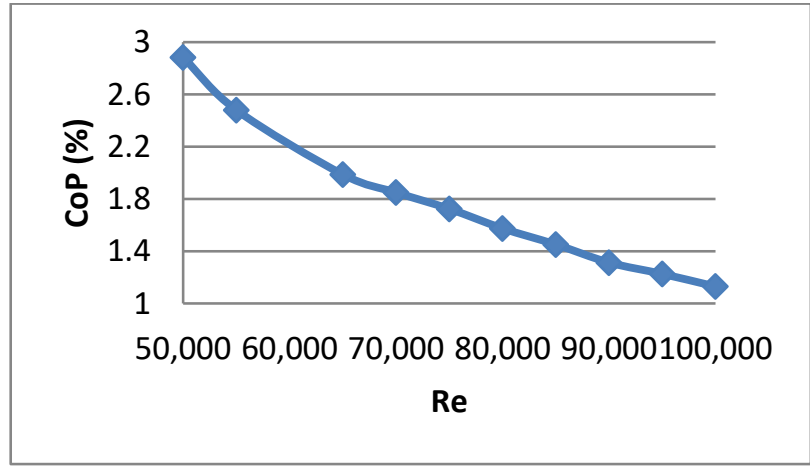

Gambar 8. Grafik coefficient of power fungsi bilangan Reynolds

Seperti yang terlihat pada Gambar 8 yaitu grafik coefficient of power pada berbagai bilangan Reynolds, 
terlihat bahwa bilangan Reynolds paling optimum adalah pada 50.000 dimana seiring dengan peningkatan bilangan Reynolds, nilai coefficient of power menjadi semakin menurun. Hal tersebut diatas menunjukkan bahwa dengan adanya peningkatan kecepatan aliran fluida yang diwakili dengan peningkatan bilangan Reynolds tidak selalu seiring dengan peningkatan efisiensi daya-nya. Perumusan dari koefisien daya sendiri adalah perbandingan dari daya output dan daya input. Dimana daya output dihitung dengan cara mengukur tegangan dan arus, sedangkan daya input dihitung dengan mengalikan massa jenis udara, luas permukaan turbin, serta kecepatan aliran yang dipangkatkan tiga. Saat bilangan Reynolds ditingkatkan, terjadi peningkatan voltase dan arus yang diukur. Namun sebaliknya, kecepatan aliran pun turut meningkat. Sesuai dengan perumusan, kecepatan aliran dipangkatkan tiga, sehingga meski terjadi kenaikan pada voltase dan arus yang dihasilkan turbin, namun nilai daya output ini tidak mampu mengimbangi peningkatan kecepatan aliran. Sehingga seiring dengan peningkatan bilangan Reynolds, nilai koefisien daya menjadi semakin menurun.

\section{KESIMPULAN}

Berdasarkan analisa yang telah dilakukan mengenai pengaruh penambahan plat datar pengganggu di depan sudu returning pada turbin angin tipe Savonius terhadap performa turbin, didapatkan beberapa kesimpulan diantaranya adalah:

1. Pemberian plat datar pengganggu dengan $\mathrm{L} / \mathrm{d}=$ 1,3054 pada bilangan Reynolds 60.000, 75.000 dan 90.000 dapat meningkatkan performa turbin angin, yaitu peningkatan pada nilai putaran, torsi statis dan daya yang dihasilkan untuk sudut kemiringan $0^{\circ} \leq \theta \leq 90^{\circ}$.

2. Plat datar pengganggu dengan $\mathrm{L} / \mathrm{d}=1,3054$ paling optimum digunakan pada sudut bukaan $(\theta)=40^{\circ}$ pada bilangan Reynolds 60.000 dengan peningkatan nilai putaran sebesar $263 \%$ bila dibandingkan dengan nilai putaran pada turbin tanpa penghalang.
3. Plat datar pengganggu dengan $\mathrm{L} / \mathrm{d}=1,3054$ paling optimum digunakan pada sudut bukaan $(\theta)=0^{\circ}$ pada bilangan Reynolds 90.000 dengan peningkatan nilai torsi statis sebesar $730 \%$ bila dibandingkan dengan nilai torsi statis pada turbin tanpa penghalang.

4. Plat datar pengganggu dengan $\mathrm{L} / \mathrm{d}=1,3054$ paling optimum digunakan pada sudut bukaan $(\theta)=40^{\circ}$ pada bilangan Reynolds 60.000 dengan peningkatan nilai koefisien daya sebesar $460 \%$ bila dibandingkan dengan nilai coefficient of power pada turbin tanpa penghalang.

\section{UCAPAN TERIMA KASIH}

Penulis mengucapkan terima kasih yang sebesarbesarnya kepada beberapa pihak yang telah banyak membantu proses penulisan diantaranya adalah:

1. Kedua orangtua saya yang telah banyak membantu dalam hal support baik itu moral maupun material.

2. Prof. Dr. Ir. Triyogi Yuwono, DEA selaku dosen pembimbing yang tanpa lelah membimbing saya dalam proses penulisan.

3. Wira Ashari. Sahabat terbaik yang terus menyemangati saya untuk menyelesaikan jurnal ini.

4. Warga laboratorium mekanika dan mesin-mesin fluida beserta seluruh isinya termasuk geng sidang dan geng revisi yang saling menyemangati dan bertumpu satu sama lain.

5. Semua sahabat dan teman yang tidak dapat saya sebutkan namanya satu persatu.

\section{DAFTAR PUSTAKA}

[1] Altan, B.D. dan Atilgan, M. 2010. The Use of a Curtain Design to Increase the Performance of a Savonius Wind Rotors. Journal Renewable Energy, Vol. 35, Page 821-829.

[2] Altan, B.D. Atilgan, M. Aydogan, O. 2008. An Experimental Study on Improvement of a Savonius Rotor Performance with Curtaining. Journal Experimental Thermal and Fluid Science, Vol. 32, Page 1673-1678.

[3] Mohamed, M.H., McDonald, Alan T. 2011. Introduction to Fluid Mechanics. John Wiley \& Sons, Inc: New York. 